\title{
Religião na perspectiva sociológica clássica: considerações sobre Durkheim, Marx e Weber
}

\author{
Religion in classical sociological perspective: considerations on Durkheim, \\ Marx and Weber
}

Waldney de Souza Rodrigues Costa ${ }^{1}$

professordney@gmail.com

RESUMO: Tendo em vista a relevante contribuição das Ciências Sociais para a teoria da religião, pretende-se com este texto, oferecer um recurso didático a discentes que ingressam na(s) Ciência(s) da(s) Religião(ões), bem como a quem deseja iniciar-se em Sociologia da Religião. Busca-se descrever de forma sucinta como a religião é abordada por Marx, Weber e Durkheim, considerados os clássicos da Sociologia. Após breve exposição do lugar que a religião ocupa na teoria social de cada um em separado, sublinhando as suas mais relevantes contribuições e pontuando as principais críticas percebidas por comentadores, arrisca-se uma comparação entre as abordagens sociológicas da religião utilizando o recurso de separar a teoria social em três dimensões: teoria sociológica, teoria da modernidade e teoria política.

PALAVRAS-CHAVE: Religião. Teoria social. Sociologia da religião. Sociologia clássica.

ABSTRACT: Given the relevant contribution of the Social Sciences to the theory of religion, it is intended with this text to offer a didactic resource to students who enter the Religions Studies, as well as who wants to start in Sociology of Religion. It seeks to briefly describe how religion is approached by Marx, Weber and Durkheim, considered the classics of Sociology. After a brief exposition of the place that religion occupies in the social theory of each one separately, underlining their most relevant contributions and punctuating the main criticisms perceived by commentators, a comparison is made between the sociological approaches of the religion using the separation of the social theory in three dimensions: sociological theory, theory of modernity and political theory.

KEYWORDS: Religion. Social theory. Sociology of religion. Classical sociology.

\section{Considerações iniciais}

Para além das polêmicas a respeito do lugar que cada saber ocupa no campo acadêmico dedicado à religião (Camurça, 2008, p. 41-56), parece não haver dúvidas de que as ciências sociais (antropologia, sociologia e ciência política) tenham muito a

\footnotetext{
${ }^{1}$ Professor do Departamento de Ciências da Religião da Universidade do Estado do Rio Grande do Norte no Campus Avançado de Natal (UERN-CAN); Mestre e doutorando em Ciência da Religião pela Universidade Federal de Juiz de Fora (UFJF). Desenvolvendo pesquisa sobre religião, lazer e consumo entre evangélicos sob a orientação do professor Dr. Emerson Sena da Silveira.
} 
contribuir para a área. Prova disso é que a Sociologia da Religião é uma disciplina muito presente nos currículos de Ciência(s) da(s) Religião(ões). Pretende-se com este texto oferecer um recurso didático corpo discente que se inicia nesta área, não só das graduações, como também da pós, já que boa parte de ingressantes em especializações e mestrados advém de cursos variados (Artes, Teologia, Música, Letras, entre outros) nos quais talvez não tenham tido maior contato com a literatura sociológica.

Se por um lado a Sociologia é um importante recurso para o conhecimento dos “fatos religiosos”, também não se pode esquecer que religião, como fenômeno social, interessa muito à teoria social. Na síntese de Costa (2009, p. 59), “fazer sociologia de uma sociedade implica, mais tarde ou mais cedo, fazer sociologia da religião”. Na de Maduro (1981, p. 41), “a sociologia já nasceu como sociologia das religiões”. Este último, disse isso a respeito do contexto em que emergiram as primeiras abordagens sociológicas, quando entre os importantes processos que transformavam a sociedade europeia no século XIX, constatava-se uma profunda crise do cristianismo. Como o pensamento sociológico já surgiu em uma conjuntura em que o próprio conhecimento se emancipava da tutela da religião, por vezes se viu desafiado não só a analisar religiões como fatos sociais, mas também a pensar como os processos sociais mais amplos condicionam o religioso ou podem ser influenciados por ele.

É diante desse quadro que sugiram as primeiras abordagens sociológicas, de modo que aqueles que realizaram os primeiros trabalhos de sociologia tiveram que se pronunciar de alguma forma sobre religião. Alguns, mais do que dizer algo, realizaram análises aprofundadas dos fenômenos religiosos como fenômenos sociais. Por isso o prisma sociológico tornou-se muito importante para o conhecimento da religião. Sendo os estudos realizados por Durkheim, Marx e Weber, tomados como clássicos, no texto que se segue, busca-se descrever de forma sucinta suas abordagens da religião, uma vez que também são considerados os pais fundadores da sociologia.

Segundo a síntese de Sell (2013, p. 17), outros escritores, como Hubert Spencer e Auguste Comte, já haviam pensado a análise de fenômenos eminentemente sociais antes de Durkheim, Marx e Weber, mas a forma como estes três ilustraram as questõeschave sobre as quais a sociologia veio a se formar trouxe-lhes a reboque o caráter de clássicos, uma vez que desenvolveram pioneiramente importantes problemas que foram 
fundamentais para o desenvolvimento desse saber. Debruçando-se sobre tais questões, desenvolveram perspectivas tríplices dotadas de uma teoria sociológica, na qual se trabalha a dimensão metodológica e analítica; uma teoria da modernidade, em que se trabalha a dimensão empírica (os dados em si); e uma teoria política, em que se trabalha a dimensão de como agir mediante os dados (Sell, 2013, p. 27).

Diante disso, a seguir faço uma breve exposição da forma como cada um destes pioneiros sociólogos abordou a religião separadamente, buscando destacar principais contribuições e as obras mais importantes, levando em conta o que indicam alguns comentadores. Após a exposição, arrisca-se uma comparação entre as abordagens, tomando a divisão criada por Sell para entender qual o lugar da religião nas teorias destes autores. Pretende-se com isso compreender as possíveis contribuições dos clássicos da Sociologia para o estudo da religião, tal como esta se apresenta hoje.

\section{Durkheim e a religião como expressão da sociedade}

David Émile Durkheim (1858-1917) é um dos principais fundadores do pensamento sociológico, responsável pelo firmar da sociologia como ciência na França, sendo o primeiro professor a ocupar uma cadeira de sociologia em uma universidade. Para os comentadores franceses Hervieu-Léger e Willaime (2009), a obra de Durkheim é um marco da abordagem sociológica dos fatos religiosos.

Uma de suas grandes preocupações é separar a sociologia da psicologia. Ele defende o primado do social, em que “o indivíduo é entendido a partir do social, não o contrário” (Martelli, 1995, p. 61). Suas obras possuem uma forte sintonia entre si em termos metodológicos. Apesar de trabalhar temas diferentes, há um rigor que lhe é muito característico e cujos princípios gerais estão compilados no livro As regras do método sociológico (Durkheim, 2007).

Hervieu-Léger e Willaime (2009) destacam que a obra durkheiminiana está atravessada por uma concepção holista do mundo social. Em A divisão do trabalho social, sua tese de doutoramento, Durkheim (1999) preocupa-se com a coesão social, o que se torna um fio condutor dos seus trabalhos posteriores. Na tese, ele define dois tipos de solidariedade em que se fundamentam as sociedades. A primeira, considerada mecânica, a qual está pautada na consciência coletiva, e outra, a orgânica, em que, 
predominando a consciência individual sobre a coletiva, há uma diversificação maior das funções, principal característica da sociedade moderna (Martelli, 1995, p. 62).

Em outra pesquisa, publicada como O suicídio, Durkheim (2000b) questiona-se sobre a morte voluntária, aparentemente a manifestação máxima da individualidade. O autor demonstra como a decisão de tirar a própria vida está envolta de uma aura social que faz com que os que compõem uma sociedade estejam mais ou menos propensos a isso. Sua preocupação é em relação à anomia, que para ele é um estado em que o indivíduo se vê desconectado de orientações normativas sociais claras, sendo uma das causas de suicídio.

Esses trabalhos exemplificam como a integração social é uma preocupação geral da sociologia de Durkheim. Ela leva-o a uma busca pelas raízes da solidariedade orgânica e, segundo Martelli (1995), é nesse horizonte que sua abordagem da religião está inserida. Para alguns comentadores argentinos (Soneira et al, 1996), os ideais sociais formam, para Durkheim, uma consciência coletiva que existe independentemente das consciências individuais. Ele se propõe a estudar a religião por considerá-la um dos sistemas sociais mais importantes como sistema de ideais. São estes ideais que compõe uma sociedade e não somente um grupo indivíduos agregados em condições materiais, sendo o ideal moral um dos principais. Neste sentido, "estudar a religião é estudar as condições de formação desse ideal moral” (Hervieu-Léger; Willame, 2009, p. 171).

Embora alguns comentadores explorem outros textos de Durkheim (HervieuLéger; Willame, 2009, p. 179), é As formas elementares da vida religiosa a obra considerada de maior fôlego sobre a religião. Nela, ele retoma alguns elementos apontados nas obras de Hubert e Mauss e embarca em uma busca pela causa e pela função dos “fatos religiosos", assumindo que a própria institucionalidade desses fatos é exercida em prol de satisfazer a necessidade do organismo social. Seu objetivo é sublinhar retirar da análise do totemismo uma explicação universal da coesão social. Esta que pode ser considerada a obra prima de seu autor, pode ser lida, segundo Soneira et al, (1996, p. 57), tanto como uma análise antropológica do sistema de classes e do totemismo australiano, quanto como uma introdução à sociologia do conhecimento, ou, 
ainda, como uma teoria da religião, sendo esta última a contribuição que mais interessa ao campo de estudo das religiões.

Nesse trabalho Durkheim segue rigorosamente as mesmas regras apresentadas em As regras do método sociológico; apresenta uma definição própria do fato em questão, refuta das teses contrárias e trata-o como coisa. Então, para demonstrar a natureza essencialmente social da religião, ele refuta definições disponíveis e, semelhante ao que fez em $O$ suicídio, cria uma definição que, ainda que não explique cabalmente, delimite os fatos com que se pretende trabalhar. Assim, de modo particular, Durkheim concebe religião como:

[...] um sistema solidário de crenças e de práticas relativas a coisas sagradas, isto é, separadas, proibidas, crenças e práticas que reúnem numa mesma comunidade moral, chamada igreja, todos aqueles que a elas aderem. (Durkheim, 2000a, p. 32).

Perceba que religião é tomada como um sistema ao qual se procura decompor e tornam-se inseparáveis as ideias de religião e de igreja, o que salienta a primeira como coisa eminentemente coletiva. É um sistema social que une indivíduos em uma comunidade moral. Em um esforço por uma explicação imanente, define-se religião pelos seus aspectos exteriores: crenças, ritos e práticas (Soneira et al, 1996, p. 58).

$\mathrm{Na}$ definição há uma divisão clara em dois domínios, a dicotomia sagrado/profano. Durkheim os concebe em uma heterogeneidade absoluta, sendo que o sagrado se define em relação ao profano, visto que possuem naturezas opostas. O sagrado seria, para Durkheim, a diferenciação em relação a coisas tidas como impuras e teria uma origem social. Para ele, "as forças as quais o indivíduo se inclina são forças sociais” (Hervieu-Léger; Willame, 2009, p. 176). Uma vez que as coisas sacras estão acima das coisas profanas, as crenças são representações do sagrado em distinção ao profano que geram regras de conduta diante do sagrado.

Outra dicotomia importante para Durkheim é magia/religião. Ele não perde de vista que elas são frequentemente misturadas, até mesmo nas grandes religiões, mas as distingue no sentido de que a magia não exerce o papel de realidade social coletiva exercido pela religião. Embora as duas tratem de coisas sagradas e possuam um fundo social, a magia estaria mais para a ordem do indivíduo, enquanto a religião mais para a do coletivo. 
Na abordagem, Durkheim pretende ainda colocar-se no estado de espírito do crente, defendendo que isto não significa aderir a sua crença (Hervieu-Léger; Willame, 2009). Sua posição é de que, se há quem tenha a experiência do sagrado, não se pode negá-lo. A força religiosa é projetada para fora das consciências que a experimentam e isso despersonaliza as crenças. Há uma emoção profunda de origem que para Durkheim é reativada nos ritos, sendo que reativar não é repetir. A experiência de origem, ao passar por um trabalho de simbolização, socializa-se e é universalizada, ou ainda, domesticada. E ele ainda diz que, nesse percurso, algo pode se degenerar.

O estudo é pautado na literatura etnográfica disponível sobre o totemismo australiano. Durkheim toma essa forma de religião como “elementar”, mas isso não é necessariamente adotar uma posição evolucionista. Não se analisa formas mais elementares de religião para demonstrar uma suposta evolução, diferenciando as sociedades em uma suposta escala, mas em busca de algo em comum. É uma abordagem mais funcionalista do que evolucionista. Segundo Soneira et al (1996), no pensamento durkheiminiano não existe uma divisão evolucionista entre religião e ciência, pois as principais categorias de entendimento (como espaço e tempo) são tratadas como tendo origem na própria religião.

Hervieu-Léger e Willaime (2009) consideram o aspecto evolucionista uma questão menor e defendem que importa mais compreender o movimento teórico que toma o totemismo como um fato social, pois, com ele, Durkheim traz à tona a questão da dinâmica na religião, concebida como um sistema de forças mais que de ideias. Para comentadores argentinos (Soneira et al, 1996), a abordagem funcionalista de Durkheim lhe faz conceber a religião como coisa eminentemente social. O sentimento religioso nasce da dependência da sociedade e ambos, social e religioso, têm origem comum na vida coletiva. Logo, parece haver uma sinergia entre a religião e a sociedade, em que ela pode operar uma sacralização das normas de comportamento. E mais que isso, sua função social não é ajudar a pensar, mas sim a viver. Fazendo o homem atuar, ela lhe concede mais força para suportar as dificuldades da vida.

Por fim, Durkheim conclui que o totem é a objetivação da alma coletiva. O que a sociedade adora de fato é a própria sociedade em seu aspecto sacralizado (Soneira et al, 1996). O pensamento durkheiminiano identifica cada vez mais o social com o moral e 
religioso. Sendo assim, a religião é vista como uma projeção social. Logo, ela é imperecível (Hervieu-Léger; Willame, 2009, p. 199), e a igreja, uma característica constante (Martelli, 1995). E pela mediação do método sociológico seria possível enxergar a essência da sociedade por trás do totem/religião.

Muitas críticas já foram feitas à abordagem durkheiminiana. As principais são que, nessa perspectiva, perde-se de vista a diferença entre moral e religião; não se aborda aspectos importantes próprios ao religioso (como a mística e a contemplação); deixa-se escapar a influência mútua entre a religião e social; e também, que a sua herança de judaísmo condiciona seu olhar sobre a religião, sendo que a sua própria definição de sagrado dificilmente se aplica a religiões orientais.

Apesar dessas críticas, Sanchis (1997) explica que tem havido uma redescoberta das contribuições de Durkheim para se pensar religião na contemporaneidade. Sua tese é que essa renovação de interesse deve-se ao fato de que existe uma analogia entre as experiências religiosas da geração recente e a trajetória do pensamento durkheiminiano. Dentre as contribuições que o "velho Durkheim" ainda teria para se pensar os fatos religiosos está a ideia de que exista na religião algo de eterno, pois a vida social só é possível no simbolismo, e, por isso, não basta suprimir a religião, é preciso substituir! (Sanchis, 1997). Soma-se a isso a questão do papel da religião na coesão social e as efervescências coletivas que manifestam isso; a ideia de que a sociedade se recria ao se projetar na religião e a de que a vida religiosa eleva o homem acima de si, lhe capacitando para os desafios existenciais.

\section{A crítica de Marx e os marxistas}

Quanto a Karl Marx (1818-1883), há quem defenda que uma teoria da religião permeie a sua obra, mas Costa (2009, p. 20) salienta que ele jamais fez algum estudo sistemático sobre a religião, tema que aparece de forma esparsa em seus trabalhos, de modo que, se as referências de Marx à religião fossem retidas não se perderia nada de substancial de sua teoria social. Daí surge a pergunta: por que considerar Marx ou o marxismo em sociologia da religião? Hervieu-Léger e Willaime (2009), concordando com Costa (2009) acerca da abordagem marxista não consistir exatamente em uma análise sociológica da religião, respondem explicando que, apesar disso, Marx, 
juntamente com Friedrich Engels (1820-1895), colocaram em pauta muitos problemas que perduram nas abordagens sociológicas da religião até hoje.

Engels conheceu Marx quando trabalharam juntos em um jornal, e desenvolveram, a partir daí, um importante laço de amizade, sendo que Engels fez várias contribuições à obra de Marx, editando muitos de seus textos. Suas obras se distinguiram pelas importantes críticas ao sistema econômico capitalista. Nessas críticas, os temas alienação, dominação e conflito são fundamentais, pois estruturam sua análise social e, igualmente, a abordagem da religião. Eles tratam-na como uma superestrutura atravessada pelo conflito de classes, caracterizada por uma alienação que ofusca a realidade desse conflito. Logo, Marx e Engels são mais importantes pela crítica sociológica da religião em geral, do que pela análise de religiões em específico, sendo que, em sua teoria social, a crítica é a análise.

Lesbaupin (2011) destaca que para compreender o pensamento de Marx e Engels sobre religião é necessário distingui-lo a tradição vulgarizada do marxismo. A expressão “ópio do povo" é um reducionismo marxista que não representa a melhor síntese da reflexão de Marx. Costa (2009) lembra que esta expressão não é inédita. Quando a utilizou pela primeira vez na introdução de Crítica da Filosofia do Direito de Hegel (Marx, 2010), fazia referência uma ideia corrente anteriormente. Logo, é importante considerar a citação completa e não somente essa expressão:

A miséria religiosa constitui ao mesmo tempo a expressão da miséria real e o protesto contra a miséria real. A religião é o suspiro da criatura oprimida, o ânimo de um mundo sem coração, assim como o espírito de estados de coisas embrutecidos. Ela é o ópio do povo. (Marx, 2010, p. 145, grifo original).

Nota-se que antes dar a sentença (como ópio), Marx faz considerações bem diferentes (protesto, suspiro, ânimo). Elas podem ser mais bem compreendidas levando em conta suas formulações teóricas mais importantes. Mesmo não sendo um tema do qual tenha se ocupado exaustivamente, a religião atravessa toda a sua teoria social, sendo ora criticada, ora tomada para analogias (o que é mais frequente). A princípio, Marx não se ocupou da religião porque pensava que a crítica já estava terminada na Alemanha, mas no decorrer de sua elaboração teórica se viu forçado a leva-la em consideração. Tal posicionamento era mediado pela crítica materialista. 
O materialismo é a marca do pensamento de Marx. Costa (2009) aponta que consiste em uma posição filosófica que implica em uma concepção própria de homem, na qual as condições materiais condicionam suas ideias. Marx não acredita que a consciência determine a existência do homem, e sim o contrário. Para ele, não existe o homem em sentido abstrato, apenas homens reais inseridos em um contexto histórico, sendo a consciência um produto social e as condições materiais o contexto da produção. Logo, há uma precedência da produção dos meios de subsistência sobre os pensamentos. E se a produção da vida é uma relação natural e social, a vida determina a consciência dos indivíduos e não o contrário. Nessa perspectiva conclui-se que nenhuma mudança real acontece somente a partir das ideias. É necessária uma mudança material. É com isso que Marx está preocupado.

As críticas à religião surgem dessa concepção materialista. Martelli (1995) separa o materialismo em dois veios a partir das quais elas são elaboradas: dialético e histórico. No primeiro a religião é tida como causa e produto de alienação e no segundo é vista como utopia e ópio. Mas Assmann e Mate (1974) têm uma interpretação diferente. Eles separam as críticas em: filosófica (para a qual a religião é uma criação humana); política (na qual religião é uma falsa consciência da realidade); e econômica (segundo a qual religião é uma alienação das desigualdades estruturais). Estas críticas refletiriam estágios do próprio desenvolvimento do pensamento de Marx.

Para Assmann e Mate (1974), o “jovem Marx”, ainda filósofo, tem a crítica da religião como um ponto forte, enquanto que posteriormente, o "Marx maduro", um jornalista e analista social militante político, dá essa crítica por superada, estando a religião condenada a desaparecer à medida que a sociedade evoluísse para o socialismo. O que fica entre essas duas posições, segundo Martelli (1995), é a ideia da religião como ideologia, no sentido de verdade com pretensões absolutas, embora a própria noção de ideologia seja complexa e polissêmica nas obras de Marx e Engels.

Soneira et al (1996) procuram contextualizar melhor as críticas na evolução do pensamento de Marx, aproveitando a tríplice divisão que Assmann e Mate criaram. Os comentadores argentinos destacam que a crítica econômica de que o homem faz a religião e não o contrário, tão presente nos primeiros trabalhos de Marx, quando revisa 
vários autores (sobretudo Hegel), já era bem comum entre pensadores alemães, tornando-se basilar na filosofia da época.

Mas outra crítica evolui do contraste entre essa concepção filosófica e a análise material da sociedade. Se por material se entende tudo que é fruto de trabalho humano e toma-o como chave interpretativa do social, logo fica evidente que sua distribuição é bem desigual na sociedade. Desigualdade expressa na miséria de muitos. Daí que a religião não é só produção humana (crítica econômica), mas produção para atender a um fim (crítica política). É uma consciência invertida da realidade social, no sentido de ser uma ilusão necessária para uma situação que carece de ilusões. Para Marx, para sair de tal situação, é necessário abandonar o que é ilusório. Nesse ponto, o próprio Marx afirma que a crítica da religião deve evoluir para uma crítica da própria política. É aí que se inserem as analogias religiosas de sua crítica ao capitalismo. Analogias como a de que, no sistema capitalista, o homem se deixa dominar por algo que ele mesmo produziu (assim como na religião) e a do fetichismo da mercadoria, descrito por Marx como o processo pelo qual as mercadorias ganham uma forma “fantasmagórica” no mercado, parecendo dotadas de vida própria ao abstrair-se do trabalho empenhado que a gerou (Marx, 2014, p. 94).

Mas não é só como analogia que a religião aparece na teoria marxiana. Em suas análises, Marx separa estrutura (que, em termos gerais, são as condições materiais da produção da existência) e superestrutura (as produções ideais, como o direito, a arte, e também a religião). Martelli (1995, p. 46) chama a atenção para o fato de que a religião é a única das superestruturas tida por Marx como irrecuperável, não sendo passível de redenção no sistema socialista. Ela é vista como algo que reflete e reforça a alienação. Daí acreditar-se que, no socialismo, ao findar-se a alienação, a religião torna-se desnecessária. Desapareceria paulatinamente.

Uma crítica de Marx que não aparece na abordagem tríplice separada por Assmann e Mate (1974) é a da religião como utopia. Ela é mais destacada por marxistas que colocam em revelo a importância da capacidade utópica da religião e fazem uma ressalva ao autor, levando em conta que, embora a religião seja sempre imaginação, não necessariamente é alienação (Martelli, 1995, p. 46). Um brasileiro que poderia exemplificar esse posicionamento é Rubem Alves (1984). Em suma, Soneira et al 
(1996, p. 55), parafraseando Assmann e Mate (1974, p. 36), deduzem uma evolução da crítica da religião no pensamento marxiano, partindo de uma crítica da igreja, passando por uma crítica do cristianismo e da magia, até culminar em uma crítica total da religião.

A tradição marxista que emergiu, em geral, não teve muito apreço pela religião. Porém existem importantes exceções, como Rosa Luxemburgo e Antonio Gramsci que se preocupam com o papel das religiões na história (Lesbaupin, 2011); sendo que o próprio Engels realizou estudos sistemáticos sobre religiões, aparentemente mais atento que Marx, relacionando religião e classes sociais e concebendo-a como manifestação latente do imaginário social (Costa, 2009). Quanto a isso, Lesbaupin (2011) chama a atenção para o estudo comparado de Engels sobre o cristianismo primitivo e o socialismo.

Muitas críticas são feitas a Marx e aos marxistas. Merece destaque a da possibilidade da religião também ser forma de protesto e não somente uma alienação (Hervieu-Léger; Willaime, 2009, p. 25), algo tangenciado por Marx, mas que muito marxista perde de vista. Também cabe pontuar os fatos de que nem todas as bases do sentimento religioso são de origem social (Hervieu-Léger; Willaime, 2009, p. 40) e de que boa parte da crítica da religião não é aplicável a culturas não capitalistas. Além disso, tem-se a ironia do destino em que o próprio marxismo foi tido, no desenrolar da história, como uma espécie de religião secular (Martelli, 1995, p. 47).

Apesar das críticas sofridas, uma das principais contribuições de Marx para a teoria da religião é a noção de ideologia, com a qual se pode pensar a influência de uma cosmologia religiosa sobre a compreensão que os indivíduos possuem da realidade. Enfim, cabe pontuar que os teólogos Assmann e Mate (1974) concordam com as críticas postuladas por Marx à igreja como instituição, ao cristianismo e à magia. Como representantes da teologia da libertação, rejeitam apenas a crítica total da religião, deixando a pergunta a respeito do porquê de a religião ser sempre atrelada a uma alienação, defendendo a possibilidade de que ela também possa se tornar resistência dos oprimidos, o “protesto contra a miséria”.

\section{Weber, religião e a sociologia compreensiva}


Destaque entre os três teóricos tidos como clássicos, Max Weber (1864-1920) é um grande expoente da sociologia e torna-se importante para a teoria da religião porque, apesar de afirmar que não tinha "ouvido musical para a religião" (Hervieu-Léger; Willaime, 2009, p. 74), não transformou o agnosticismo metodológico empregado em uma "má vontade”. Na direção oposta, ele muito se dedicou às religiões, sendo entre os clássicos, “o que mais tem influenciado a sociologia da religião” (Mariz, 2011, p. 67). A própria noção de “religiões mundiais” popularizou-se com a sua obra:

Por "religiões mundiais" entendem-se aqui, de maneira totalmente isenta de valor, aqueles cinco sistemas religiosos ou religiosamente condicionados de regulamentação da vida que souberam reunir em torno de si quantidades significativamente grandes de seguidores: as éticas religiosas confuciana, hinduísta, budista, cristã e islâmica. Junta-se a essas como sexta religião [...] o judaísmo, seja por conter pressupostos históricos decisivos para a compreensão das duas últimas citadas, seja por sua significação histórica intrínseca, em parte rela, em parte presumida, para o desenvolvimento da ética econômica do Ocidente (Weber, 2016, p. 19).

Weber destaca-se, como foi possível perceber na citação, por assumir a possibilidade de uma interação recíproca entre a religião e a sociedade (Martelli, 1995, p. 76), mas antes de tratar disso cabe diferencia-lo de seus pares. Devemos lembrar que, enquanto Durkheim, preocupado com a coesão social, adota um holismo que elege a função dos fatos sociais como unidade de análise; Marx, preocupado com a emancipação das desigualdades, adota o materialismo e elege a produção. Weber se afasta dos dois. De Marx por conceber que a interação humana se dá em vários sentidos e categorias e não se reduz a uma luta de classes, e de Durkheim, porque ao invés de lançar o seu olhar sobre o todo social (ou holos), volta a sua atenção para o indivíduo, adotando o que ficou conhecido como individualismo metodológico e elegendo a ação social como unidade de análise.

Por ação social, Weber (2000) entende aquela em que o indivíduo refere-se ao comportamento de outros, por eles se orientando. Nesse sentido, a sociedade é fruto de interações que se dão por um conjunto de ações sociais de indivíduos. Para Weber, 
existem quatro tipos de ações sociais ${ }^{2}$. Não sendo aqui o melhor espaço para exaurir os tipos de ação, cabe frisar que mesmo a ação orientada por motivos religiosos ou mágicos é considerada uma ação relativamente racional. Esse é um aspecto fundamental para a compreensão do empreendimento weberiano. Partindo do pressuposto de que seja possível interpretar a realidade social através de atos dos indivíduos, atribui à sociologia a tarefa de descrever o curso e o efeito das ações sociais, a fim de compreender o sentido dado à ação. Ela encarregar-se-ia de reduzir os conceitos abstratos à ação compreensível, que é sempre ato individual. Por isso essa postura é conhecida como sociologia compreensiva. É uma ciência social que busca tornar compreensível a ação do indivíduo, não emitindo um juízo de valor, mas interpretando o sentido da ação social.

Com esse projeto, o grande empreendimento de Weber é entender como foi possível ao Ocidente, e só nele, conceber um racionalismo econômico tal que gerou o capitalismo moderno, dotando-o de universalidade. É em meio a isso que religiões lhe interessam. Weber faz sociologia da religião fazendo sociologia da racionalidade. Para ele, religião possui “uma boa dose de legalidade própria” (Weber, 2016, p. 20). Dotada de autonomia relativa, não apenas reflete o social (como em Durkheim e Marx), como também pode alterá-lo. O condicionamento religioso da conduta de vida é, para Weber, um dos fatores determinantes da ética econômica (somente um deles!). Logo, estudar as “religiões mundiais” é estudar diferentes éticas que estruturaram diferentes ações econômicas em diferentes civilizações. O objetivo ainda é o mesmo: compreender a especificidade da sociedade capitalista ocidental.

Weber possui diferentes trabalhos sobre religiões, mas a obra mais conhecida é A ética protestante e o "espírito" do capitalismo (Weber, 2004). Nela, o autor trabalha com uma noção alternativa à de causalidade, a “afinidade eletiva”. Nela, dois fenômenos que não se causam, mantém reciprocidade, de modo a corroborarem para um desenvolvimento comum. O objetivo de Weber é demonstrar a afinidade eletiva existente entre uma ética religiosa protestante, tomada a partir da concepção de vocação (beruf) de Lutero, e o desenvolvimento da racionalidade capitalista moderna.

\footnotetext{
${ }^{2}$ Racional quanto a fins, racional quanto a valores, afetiva e tradicional (Weber, 2000, p. 15).
} 
Nessa obra, Weber, ao buscar uma resposta para o tipo de racionalidade que tornou viável o atual modelo de capitalismo, defronta-se com a religião, particularmente o protestantismo (Mariz, 2011, p. 73). Seu objetivo principal é compreender em que medida algumas forças religiosas interviram na expansão do sistema capitalista no mundo (Soneira et al, 1996, p. 64). Diferente de Durkheim, ele não parte de uma definição pretensamente precisa, mas de um compêndio de declarações de Benjamin Franklin utilizado para caracterizar o espírito do capitalismo. A partir disso, pergunta-se pelos elementos da ética protestante que contribuíram para se chegar a tal. Weber apresenta como o conceito de vocação de Lutero foi reinterpretado sob a égide do puritanismo, no sentido de uma missão sagrada. Sendo assim, na reapropriação de origem calvinista, o trabalho profissional foi tomado como um encargo divino, devendo ao crente ter a obrigação de trabalhar e acumular riqueza. Há, desta forma, uma afinidade eletiva entre o protestantismo ascético e o espírito do capitalismo moderno, manifesta em uma ascese intramundana. Diferente do ermitão que se isola da sociedade, o puritano é desafiado pela sua fé a manter-se puro dentro das relações "mundanas”. Uma vez que Deus já havia predestinado os salvos e não havia como alterar o destino, o êxito profissional tornara um sinal de salvação. É quando essa conduta religiosa de vida é transformada na ética do trabalhador e do empresário que se tem o desenvolvimento do capitalismo, tal como se vê hoje.

É importante salvaguardar que, em Weber, à medida que o capitalismo evolui, há um processo gradativo de autonomização até não depender mais do condicionamento religioso (Martelli, 1995, p. 80). É como se religião e economia se encontrassem em afinidade eletiva e seguissem em separado, cada uma o seu caminho. A tese é de que a ética protestante calvinista conferiu algo de particular ao capitalismo moderno, o que ajuda na compreensão da especificidade do Ocidente. Se ela é verdade, faltava verificar a relação entre outras éticas religiosas e o racionalismo econômico. É a esse projeto que Weber estava dedicando-se no fim de sua vida (Weber, 2016).

Mas a abordagem weberiana da religião possui aspectos para além desse projeto mais amplo. Com uma obra enciclopédica, ele também estuda a relação da religião com outras esferas sociais (Hervieu-Léger; Willaime, 2009, p. 91-98). E também tem uma contribuição importante pata a teoria da institucionalização religiosa. Para compreendê- 
la é preciso retomar a noção de tipo ideal, tão presente em sua sociologia. Trata-se de uma das ferramentas criadas por Weber (2000) para reduzir conceitos abstratos à ação compreensível. Representa uma caricatura da realidade que permite entendê-la, mas que não é encontrada na mesma. Não é ideal no sentido de um modelo valorizado positivamente, mas no sentido de não ser encontrado no mundo real de fato, apenas no campo das ideias. Nessa construção, acentuam-se determinados traços da realidade para poder criar uma ferramenta para interpretá-la. É uma ficção teórica para pensar o real. Quase uma utopia. Mas não é pura imaginação e sim um caminho entre a abstração e a ação concreta, construído para conjugar as variantes, a fim de que a pluralidade das situações empíricas não inviabilize a discussão.

Weber (2000) formula uma sociologia da religião baseada em tipos ideais. A tipologia que se tornou mais importante para a literatura é a tríade profeta, mago e sacerdote. O sacerdote seria o agente da fé especializado, um funcionário de uma instituição permanente, regular e organizada, tendo em vista influir sobre os deuses. Ele se opõe ao mago que faz um uso individual e ocasional dos poderes sagrados. Por último, não menos importante, estaria o profeta, o portador de uma revelação mística ou ético-religiosa que transcende a instituição. Dotado de um carisma capaz de agregar fiéis, ele geralmente se opõe ao sacerdote na disputa pela confiança dos leigos, mas geralmente tende a formar outra instituição, e assim, dar início a outro ciclo de institucionalização religiosa (Weber, 2000, p. 294-310).

Como é possível perceber, a sociologia weberiana tem muito a contribuir para uma teoria da religião. Mas ela não ficou imune a críticas. As principais são as citadas por Soneira et al (1996, p. 67). Os comentadores argentinos destacam que: não existe tanta diferença entre o ascetismo católico e o calvinista como Weber supõe; as forças motrizes da atividade econômica podem derivar de motivos completamente diferentes; e também, que suas observações sobre o protestantismo parecem estar deslocadas geograficamente, já que, na Inglaterra, o capitalismo parece ter se desenvolvido por motivos bem diferentes dos religiosos.

Não obstante, as contribuições weberianas têm sido reavaliadas pelo trabalho de nomes expoentes na literatura sociológica, entre os quais se destaca Pierre Bourdieu (2007). Uma das mais discutidas é a teoria da secularização, da qual fazem parte dois 
movimentos principais. Um é o de desmagificação, quando a religião vai perdendo o estado de fundamento social e abrindo caminho para a autonomização de outras esferas. Outro é o desencantamento do mundo que, de maneira geral, é o avanço das formas racionais de se organizar a vida, processo que começou com as éticas religiosas e evoluiu até chegar a um patamar de negação de toda explicação mágica, transcendente ou sobrenatural da realidade, prezando pela explicação empírica.

Estes movimentos integram o processo de racionalização que, aliado aos movimentos de intelectualização e especialização sistemática, traz como consequência a perda dos valores últimos na vida pública. Estes são transmitidos para um reino transmundano ou para as relações imediatas entre indivíduos. E, aí, nada garante que com maior grau de racionalidade do mundo se consiga maior felicidade ou liberdade. Pelo contrário! Weber (2004), um tanto pessimista, não só não faz apologia a essa racionalização crescente, como reconhece que ela pode nos afogar em uma "crosta de aço” de burocracias.

\section{Breve comparação entre as abordagens}

A partir do que foi apresentado, arrisco aqui uma breve comparação entre as abordagens, tomando por base a divisão didática criada por Sell (2013) para apresentar as teorias de Durkheim, Marx e Weber. O autor separou a produção teórica dos clássicos em três grandes campos, teoria sociológica, teoria da modernidade e teoria política. Como a ideia é fazer deste texto um recurso didático, ao longo desta parte, serão apresentadas imagens com quadros comparativos entre as abordagens para melhor apreensão do conteúdo.

Lembrando que a sociologia surgiu da tentativa de se compreender as mudanças sociais causadas pela emergência dos paradigmas modernos na sociedade europeia no século XIX e pensar uma forma de administrá-las, tem-se que a sociologia é, em termos mais gerais, uma teoria da modernidade (Sell, 2013). Para tecê-la, os clássicos tiveram que discorrer sobre a melhor forma como se poderia entender esta modernidade (teoria sociológica), e também, uma teoria política que apontasse como agir diante das conclusões a que se chegasse. Partindo dessa aproximação, pergunta-se agora pelo lugar ocupado pela religião em cada uma dessas três dimensões teóricas. 


\section{QUADROCOMPARATIVOSOCTOLÓGICOMETODOLOCGICO

\begin{tabular}{|c|c|c|c|}
\hline & MARX & DURKHEIM & WEBER \\
\hline Método & $\begin{array}{l}\text { Materialismo } \\
\text { histórico com } \\
\text { atenção à } \\
\text { produção }\end{array}$ & $\begin{array}{c}\text { Abordagem } \\
\text { funcionalista dos } \\
\text { fatos sociais }\end{array}$ & $\begin{array}{l}\text { Sociologia } \\
\text { compreensiva da } \\
\text { ação social }\end{array}$ \\
\hline$\Lambda$ Rcligião & $\begin{array}{l}\text { Pode ser um } \\
\text { aspecto alienante } \\
\text { do conflito de } \\
\text { classes }\end{array}$ & $\begin{array}{l}\text { Descmpenha um } \\
\text { papel na cocsão } \\
\text { social, sendo } \\
\text { expressão da } \\
\text { sociedade }\end{array}$ & $\begin{array}{l}\text { Pode influenciar } \\
\text { fortemente a ação } \\
\text { do individuo }\end{array}$ \\
\hline
\end{tabular}

Figura 2 - Quadro comparativo entre Durkheim, Marx e Weber - Teoria Sociológica/metodologia.

A começar pela teoria sociológica, Sell divide-a em epistemologia e método. Epistemologicamente, Durkheim defende o primado do objeto, seguindo a tradição positivista, adotando uma perspectiva holista na qual a religião aparece como uma espécie de espelho através do qual se pode apreender o todo. Já Marx, embora também tenha um horizonte holista, assume o primado do devir e da dialética. Neste caso a religião também é atravessada pelo conflito de classes inerente ao todo. E Weber, diferente dos dois, como foco no indivíduo, adota o primado do sujeito. Atento à ação social, sua posição é de que a religião possa exercer no indivíduo algo que pode influir sobre a macroestrutura social (vide Figura 1).

Quanto ao método, Durkheim, numa abordagem funcionalista dos fatos sociais, atenta-se ao papel que a religião desempenha na coesão social, concluindo que ela é uma projeção da própria sociedade, criada por ela mesma. Já o materialismo histórico adotado por Marx

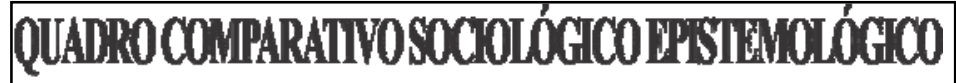

\begin{tabular}{|c|c|c|c|}
\hline & MARX & DURKHEIM & WEBER \\
\hline Epistemologia & $\begin{array}{c}\text { Holismo, } \\
\text { Primado do devir }\end{array}$ & $\begin{array}{l}\text { Holismo, } \\
\text { Primado do } \\
\text { objeto }\end{array}$ & $\begin{array}{l}\text { Individualismo, } \\
\text { Primado do } \\
\text { sujeito }\end{array}$ \\
\hline A Religião & $\begin{array}{l}\text { Atravessada pelo } \\
\text { conflito de classes }\end{array}$ & $\begin{array}{l}\text { Expressão da } \\
\text { socicdadc }\end{array}$ & $\begin{array}{l}\text { Pode influenciar a } \\
\text { cstrutura social }\end{array}$ \\
\hline
\end{tabular}

Figura 1 - Quadro comparativo entre Durkheim, Marx Weber - Teoria Sociológica/epistemologia.

deixa-o atento à produção social e o faz assumir que, como produto social, a religião é um aspecto alienante do conflito de classes. E Weber, por sua vez, buscando interpretar a ação social do indivíduo por meio de um método compreensivo, tem a religião como um aspecto que pode determinar a ação.

Agora, quanto à teoria da modernidade, a sociologia durkheiminiana apresenta, desde a análise da divisão do trabalho social, a anomia como grande problemática do 
mundo moderno. Para Durkheim, este é um problema sobre o qual a religião tem algo a dizer e, por isso, sempre terá um lugar no futuro da sociedade. Marx e os marxistas já veem de forma diferente. Toma-se o grau elevado de exploração como principal característica do moderno mudo capitalista, algo que deveria ser vencido com a emergência do socialismo. Nesse enfoque, sendo a religião uma alienação da exploração, estaria fadada a desaparecer da existência humana. O diagnóstico de Weber também não é otimista para com a religião. Para ele, uma das principais características da modernidade é o avanço do racionalismo da dominação do mundo. Embora seja verdade que exista algum espaço para renovação pelo carisma, essa racionalização, que no pensamento weberiano já é problemática em si mesma, levaria cada vez mais os indivíduos a encurtarem o espaço do religioso, agravando o problema da perda de sentido e de liberdade (vide Figura 3). 
Por fim, na teoria política os clássicos apresentam propostas para lidar com as contradições próprias do mundo moderno. Durkheim acreditava no potencial emancipador da modernidade e que os problemas principais advinham de um descompasso entre a estrutura social e as formas de interação social. Desta forma, tratava-se de um problema de ordem moral, que deve ser contornado através da emergência de uma nova moral, mas que não seria composta pela religião, mas pelo Estado laico. Marx, tomando o comunismo como o fim da história, também via o futuro com bons olhos. Porém, como é salientado por Martelli (1995), no desfecho da história a religião seria irrecuperável, devendo ser expurgada da sociedade. Quanto a Weber, sua proposta é que se deva burocratizar o sistema político de forma a se evitar o oportunismo, pois não se pode confiar na ética individual (Weber, 2011); mas parece ter
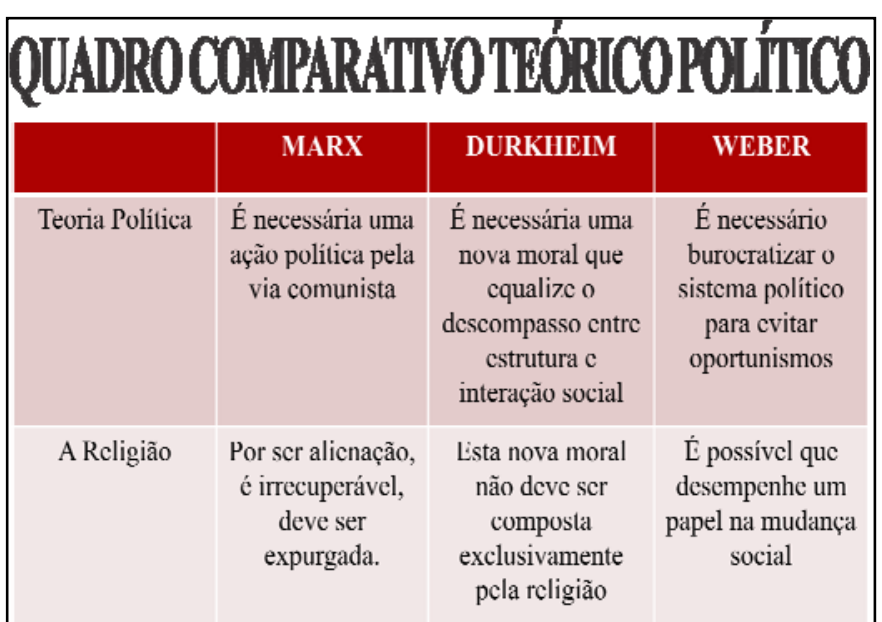

Figura 4 - Quadro comparativo entre Durkheim, Marx Weber - Teoria política. herdado de Nietzsche uma desconfiança do controle racional do mundo social (Sell, 2013, p. 160). Sendo assim, levando em consideração o carisma, diferente de Durkheim e Marx, acredita que é possível que a religião exerça algum papel na mudança social (Martelli, 1995, p. 74).

Esta brevíssima apreciação não dá conta de todas as repercussões que a religião teve nas teorias dos clássicos e deixou uma variedade enorme de análises possíveis de fora. Contudo, ao colocar a religião dentro do quadro didático criado por Sell (2013), possibilita entender a sua relação com as

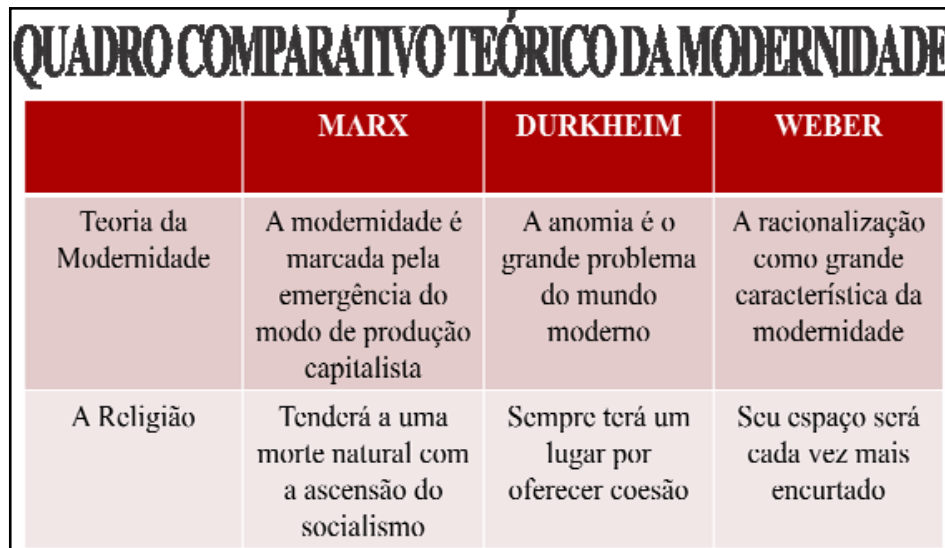

Figura 3 - Quadro comparativo entre Durkheim, Marx Weber - Teoria da modernidade. 
formulações teóricas mais gerais. Espera-se que isso possa contribuir para discussões que aprofundem e ultrapassem os tópicos levantados, sobretudo em meio aos iniciantes em Ciência(s) da(s) Religião(ões).

\section{Considerações finais}

Espera-se que a apresentação feita neste texto, ainda que de forma não cabal, possa contribuir para a iniciação no universo da sociologia da religião. O grande ponto fraco dessa análise aparentemente densa é que seu caráter sucinto exige seleção de alguns tópicos considerados mais importantes no quadro geral das teorias. Muitos outros foram deixados de fora e, a depender dos objetivos de quem quer se apropriar, eles podem ser considerados mais pertinentes do que os que foram discutidos.

Na reavaliação da sociologia de Durkheim, Marx e Weber, salta aos olhos que, em seus projetos, sociologia de qualquer coisa é, antes de qualquer coisa, sociologia. Uma teorização do social, composta, segundo Sell (2013), por uma teoria sociológica, uma teoria da modernidade e uma teoria política. Logo, religião, assim como a ciência, a arte, a política ou qualquer outra esfera, não é a preocupação mais imediata, não é importante em si mesma. Compreender essa postura é essencial para captar os limites e a potencialidades das teorias sociológicas da religião.

Por fim, como a religião apresenta-se hoje com uma face totalmente renovada, talvez seja conveniente perguntar-se a respeito da pertinência das abordagens clássicas (Sanchis, 1997, p. 11). Todavia, sendo essas mesmas abordagens as que abriram caminho para a afirmação da sociologia como ciência, levantando questões que ainda persistem, parece útil retomar suas principais contribuições e avalia-las em conjunto. Sobretudo no Brasil, cujo desenvolvimento das Ciências Sociais culminou em uma espécie de especialização em que cada vertente religiosa foi abordada preferencialmente a partir de uma perspectiva clássica específica, sendo Marx utilizado em análises do catolicismo institucional, Weber nas abordagens de protestantismo e pentecostalismo e Durkheim nos estudos das religiões de matriz afro-brasileira e catolicismo popular (Montero, 1999, p. 330). Coloca-las num horizonte comum talvez seja um caminho para despertar a criatividade... Teórica e empírica. 


\section{REFERÊNCIAS}

ALVES, Rubem. O suspiro dos oprimidos. São Paulo: Editora Paulinas, 1984.

ASSMAN, Hugo; MATE, Reyes. Introducción. In: MARX, Karl; ENGELS, Friedrich. Sobre la religión. Madrid: Ed. Sígueme, 1974. p. 9-37.

BOURDIEU, Pierre. A economia das trocas simbólicas. São Paulo: Perspectiva, 2007.

CAMURÇA, Marcelo. Ciências sociais e ciências da Religião: polêmicas e interlocuções. São Paulo: Paulinas, 2008.

COSTA, Joaquim. Sociologia da religião: uma breve introdução. Aparecida: Editora Santuário, 2009.

DURKHEIM, Émile. As regras do método sociológico. 3. ed. Trad. Paulo Neves. São Paulo: Martins Fontes, 2007.

As formas elementares da vida religiosa: o sistema totêmico na Austrália. Trad. Paulo Neves. São Paulo: Martins Fontes, 2000a.

O suicídio: estudo de sociologia. Trad. Mônica Stahel. São Paulo: Martins Fontes, 2000b.

Da divisão do trabalho social. 2. ed. Trad. Eduardo Brandão. São Paulo: Martins Fontes, 1999.

HERVIEU-LÉGER, Danièle; WILLAIME, Jean-Paul. Sociologia e religião: abordagens clássicas. Trad. Ivo Storniolo. Aparecida: Ideias \& Letras, 2009.

LESBAUPIN, Ivo. Marxismo e religião. In: TEIXEIRA, Faustino (org.). Sociologia da religião: enfoques teóricos. 4. ed. Petrópolis: Vozes, 2011. p. 13-35.

MADURO, Otto. Religião e luta de classes: quadro teórico para a análise de suas interrelações na América Latina. Trad. Clarêncio Neotti e Ephraim Ferreira Alves. Petrópolis: Vozes, 1981.

MARIZ, Cecília Loreto. A sociologia da religião de Max Weber. In: TEIXEIRA, Faustino (org.). Sociologia da religião: enfoques teóricos. 4. ed. Petrópolis: Vozes, 2011. p. 67-93.

MARTELLI, Stefano. A religião na sociedade pós-moderna: entre secularização e dessecularização. Trad. Euclides Martins Balancin. São Paulo: Paulinas, 1995.

MARX, Karl. O capital: crítica da economia política, livro I. 33. ed. Trad. Reginaldo Sant’anna. Rio de Janeiro: Civilização Brasileira, 2014.

Crítica da filosofia do direito de Hegel. São Paulo: Boitempo, 2010. 
MONTERO. Paula. Religiões e dilemas da sociedade brasileira. In: MICELI, Sergio (org.). O que ler na ciência social brasileira. São Paulo; Brasília: Anpocs; Capes, 1999. p. 327-367.

SANCHIS, Pierre. Ainda Durkheim, ainda a religião. In: ROLIM, Francisco (org.). A religião numa sociedade em transformação. Petrópolis: Vozes, 1997. p. 11-31.

SELL, Carlos Eduardo. Sociologia clássica: Marx, Durkheim e Weber. 4. ed. Petrópolis: Vozes, 2013.

SONEIRA, Abelardo et al. Sociologia de la religión. Buenos Aires: Docencia, 1996.

WEBER, Max. Ética econômica das religiões mundiais: ensaios comparados de sociologia da religião. Petrópolis, RJ: Vozes, 2016.

A política como vocação. In: Ciência e política: duas vocações. São Paulo: Cultrix, 2011. p. 65-157.

A ética protestante e o "espírito” do capitalismo. Trad. José Marcos Mariani de Macedo. Ed. Antônio Flávio Pierucci. São Paulo: Companhia das Letras, 2004.

Economias e Sociedade. 4. ed. Brasília: Editora da UNB, 2000. 